\title{
Evaluation of polymorphic variants in apoptotic genes (Bcl-2 / Bax) and their roles in the development of myeloproliferative disorders (hematological malignancies) a case-controlled study.
}

Mamdouh Shafig Moawad

University of Tabuk

Faris J J Tayeb

University of Tabuk

Rashid Mir ( $\square$ rashidmirtabuk@gmail.com )

University of Tabuk https://orcid.org/0000-0002-4014-2332

\section{Research Article}

Keywords: Apoptotic genes, Bcl-2 gene, Bax gene, CML-Chronic myeloid leukemia, PV: Polycythemia vera, ET- Essential thrombocythemia

Posted Date: February 28th, 2022

DOI: https://doi.org/10.21203/rs.3.rs-1386196/v1

License: (9) This work is licensed under a Creative Commons Attribution 4.0 International License. Read Full License 


\section{Abstract}

\section{Background:}

BCL2 and Bax play important roles in the regulation of apoptosis. The Bax-G(-248)A AND Bcl-2$938 \mathrm{C}>\mathrm{A}$ polymorphisms in the promoter region were associated with low Bax expression, and high Bcl-2 expression, respectively. These likely affect on hematological malignancies on different parameters such as advanced stage, treatment resistance, and short overall survival. This is a case-controlled study aimed to evaluate the association of $\mathrm{Bcl}-2-938 \mathrm{C}>\mathrm{A}$ and $\mathrm{Bax}-248 \mathrm{G}>\mathrm{A}$ in leukemias causation.

\section{Methodology:}

The study included 218 subjects, among which 108 were leukemia patients and 110 healthy controls, and $\mathrm{G}(-248) \mathrm{A}$ and $\mathrm{Bcl}-2-938 \mathrm{C}>\mathrm{A}$ genotyping was detected by using amplification-refractory mutation system PCR.

\section{Results:}

The Bcl-2 -938 C>A polymorphism was found in $22 \%$ of the leukemia cohort and $10 \%$ of normal controls with a significant difference in genotype and allele frequency between the two groups $(P=0.025)$. At the same time, the Bax-248G>A polymorphism was found in $6.48 \%$ of the leukemia cohort and $4.54 \%$ of normal controls with a significant difference in genotype and allele frequency between the two groups ( $P$ $=0.048$ ). It was indicated that the Bcl-2 -938 AA genotype was associated with an increased risk of leukemia in the codominant inheritance model $(\mathrm{OR}=3.17,95 \% \mathrm{Cl},(1.33-7.53) ; \mathrm{p}=0.009)-(\mathrm{Bcl}-2 \mathrm{CC}$ vs. $A A)$. A significant association was also reported with $B c l-2$ CC VS (CA+AA) genotype in the dominant inheritance model $(\mathrm{OR}=1.86,95 \% \mathrm{Cl}=1.05-3.29, \mathrm{P}=0.03)$. A significant association was also reported with the $\mathrm{Bcl}-2(\mathrm{CC}+\mathrm{CA})$ vs $(\mathrm{AA})$ genotype in the recessive inheritance model $(\mathrm{OR}=2.53,95 \% \mathrm{Cl}=1.13-5.68$, $P=0.02)$. Similarly, our data suggested that the $A$ allele significantly increased the risk of leukemia compared to the $\mathrm{C}$ allele. $(\mathrm{OR}=1.79,95 \% \mathrm{Cl}, 1.18-2.69 ; \mathrm{P}=0.005)$. In case $\mathrm{Bax}-248 \mathrm{GA}$ genotype was associated with an increased risk of leukemia in codominant inheritance model $(\mathrm{OR}=1.87,95 \% \mathrm{Cl},(0.56$ 6.21); $p=0.017$ ( $B c l-2$ GG vs. GA). A significant association was reported with Bax-248 GG VS (GA+AA) genotype in the dominant inheritance model $(\mathrm{OR}=1.98,95 \% \mathrm{Cl}=1.14-3.45, \mathrm{P}=0.041)$. Our data indicated that the Bcl-2 -938 A allele significantly increased the risk of leukemia compared to the $G$ allele. $(O R=1.63$, $95 \% \mathrm{Cl}, 1.03-2.58 ; \mathrm{P}=0.035)$.

\section{Conclusion:}

The presence of this single nucleotide polymorphism in BCL2 -938 C>A and BAX-248G>A in leukemia patients critically increases the susceptibility to leukemia influences the response to treatment and overall survival. Our data indicated that A allele of BCL2-938 C>A and BAX-248G $>A$ gene significantly increased the risk of developing the leukemia compared to $G$ allele. The data from the current study provide evidence that BCL2-938C $>A$ and $B A X-248 G>A$ polymorphisms may be useful in predicting clinical outcomes of patients with leukemia. 


\section{Introduction}

leukemia is common blood cancer, affecting 4.2 per $10^{\wedge} 5$ of the population yearly [1]. [2, 3]. Generally, different cancers present evading apoptosis as a potetential signature of cancers affecting apoptosis. When cell cycle is abnormally interrupted, apoptosis may void, causing syndromes such as cancers $[4,5]$. In this regards, $\mathrm{Bcl}-2$-family proteins such as $\mathrm{Bcl}-2$ and $\mathrm{Bax}$ are crucial regulators in maintaining mitochondrial integrity and apoptosis $[6,7]$.

BCL-2 is primarily identified as an anti-apoptotic protein and an inhibitor of cell multiplication [8]. During cellular stress, BCL-2 can inhibit Bax/Bak pore-formation at mitochondria. In this manner, $\mathrm{BH} 3$ domains provide an avenue for BCL-2 conformation changes, which interfere with the allosteric pore-formation of Bax protein [9].

Conclusively, Certain single nucleotide polymorphisms (SNPs) are postulated to increase burdens of cancer progression and treatment refractoriness. Examples are SNPs that affect apoptotic genes Bcl-2, Bax, and MCL-1 [10]. Consequently, Bcl-2 gene overexpression in leukemias may be seen as a clonally distinguished phenotype. In this instance, Bcl-2 is shown to be over-expressed with P2 promoter SNP 938A/A homozygous genotype [11].In chronic lymphocytic leukemia (CLL), -938A/A is independently correlated to short progression-free survival (PFS) [11]. Furthermore, higher Bcl-2 expression in cancers can predict treatment resistance and, therefore, over-accumulated cancer clones [12]

Bax protein is located at chromosome 19q13.3. It is encoded with a promoter and six exons [13]. The Bax promoter can attach to different transcription factors and regulator proteins such as the p53 response element, canonical E-box, the TATA box, and the NF-KB binding site [13]. Bax has been widely studies on different cancers, A meta-analysis of 7 separate studies of 1772 cases and 1708 controls found that Bax$248 \mathrm{G}>\mathrm{A}$ alone genotype associated with human risk cancers [14].

As known, intracellular hemostasis relies on the anti-apoptotic/ pro-apoptotic mechanism. The leading players are BCL2 family proteins, the anti-apoptotic regulator Bax and the pro-apoptotic BCL-2 proteins $[15,16]$. SNPs on Bcl-2 and Bax gene promoters have been extensively studied. The common SNPs Bcl-2$938 \mathrm{C}>\mathrm{A}$ (rs2279115) and (or) Bax-248G > A(rs4645878) shows altering the gene expression in a pathogenic-fashion, for example, chronic leukemias and are likely associated with Bcl-2 over-expression by rs 2279115 or the Bax under-expression by rs 4645878 of the encoded genes [11, 17]. This is a casecontrolled study aimed to investigate the effects of promoter SNPs Bcl-2-938C >A (rs2279115) and Bax$248 \mathrm{G}>\mathrm{A}$ (rs4645878) on Leukaemias cancers, and hence, to estimate the polymorphisms significance in Leukaemias prognostication.

\section{Material And Methods Study population:}


The present study included 108 clinically confirmed leukemia patients and 110 healthy controls. We have excluded any patients with any previous history of chronic disease from this study. The Leukemia patients were collected from different hospitals from the Tabuk region-(King Khaled hospital and Kind Fahd special hospital and armed force hospital -Tabuk). All patients obtained Patient consent forms before sampling.

\section{Inclusion Criteria}

The study included 108 clinically confirmed cases of leukemia patients. The study excluded lymphoma patients. The diagnosis was confirmed by bone marrow hyperplasia, splenomegaly, hepatomegaly etc.

\section{Exclusion criteria:}

The exclusion criteria included patients with a history of any other significant malignancy.

\section{Sample Collection}

A $3 \mathrm{ml}$ peripheral blood sample was collected in EDTA vials from all patients after obtaining informed consent from each patient. The samples were collected after the approval letter was obtained from the concerned Institutional Ethics Committee.All patients obtained Patient consent forms before sampling.

\section{Selection Criteria of Healthy Controls:}

A healthy control cohort was established from participants visiting for a routine check-up at the Hospital. The study included 110 healthy controls ranging from 20 to 50 years of age, visiting Hospital for a routine check-up. The controls were enrolled from the general population of the same geographical region. A regular medical check-up was conducted (CBC, KFT, LFT, etc.), and a history of illness, if detected, was recorded by a health practitioner. Those who appeared healthy without any history of any significant disease or other chronic diseases were considered normal. In addition, a standard questionnaire was used to document the socio-demographical characteristics such as age, sex, and lifestyle.

\section{Genomic DNA extraction from peripheral blood:}

DNA was extracted using DNeasy Blood Kit (Cat No. 69506) Qiagen (Germany) as per the manufacturer's instructions. The DNA was dissolved in nuclease-free water and stored at $4^{\circ} \mathrm{C}$ until use. The extracted DNA was dissolved in nuclease-free water and stored at $4^{\circ} \mathrm{C}$ until use. The quality of the extracted DNA was checked by running the sample in $1 \%$ agarose gel. The quantity of the extracted DNA is determined by absorbance at $260 \mathrm{~nm}$ and 280nm using a spectrophotometer or NanoDrop ${ }^{\text {TM }}$ (Thermo Scientific, USA).

\section{Genotyping of Bcl-2 rs2279115 C/T}

The Bcl-2 rs2279115C > T SNP and Bax - 248G > A SNPrs4645878 genotyping was detected using amplification-refractory mutation system PCR (ARMSPCR). Primer3 software was used to design the ARMS primers, as shown in Table 1. 
Table 1

ARMS primers for $\mathrm{Bcl}-2$-938 C > A rs2279115 gene polymorphism

\begin{tabular}{|c|c|c|c|c|}
\hline & & Primer sequence & $\begin{array}{l}\text { Product } \\
\text { size }\end{array}$ & Annealing tempt \\
\hline \multicolumn{2}{|l|}{$\mathrm{Bcl}-2-\mathrm{FO}$} & 5'-CCGGCTCCTTCATCGTCTCC-3' & $300 \mathrm{bp}$ & $58^{\circ} \mathrm{C}$ \\
\hline \multicolumn{2}{|l|}{$\mathrm{Bcl}-2-\mathrm{RO}$} & \multicolumn{3}{|l|}{ 5'-CCCAGGAGAGAGACAGGGGAAAT-3' } \\
\hline $\mathrm{Bcl}-2-\mathrm{FI}$ & A & 5'-AАТААААСССТСССССАССАССТ-3' & $220 b p$ & \\
\hline $\mathrm{Bcl}-2-\mathrm{RI}$ & C & 5'-CCCTTCTCGGCAATTTACACGC-3' & $121 b p$ & \\
\hline \multicolumn{5}{|c|}{ ARMS primers for Bax G (-248)A SNP rs4645878 gene polymorphism } \\
\hline \multicolumn{2}{|l|}{ Bax Fo1 } & 5'-CCTGGAAGCATGCTATTTTGGGGCCT-3' & $323 \mathrm{bp}$ & $65^{\circ} \mathrm{C}$ \\
\hline \multicolumn{2}{|l|}{ Bax Ro1 } & \multicolumn{3}{|l|}{ 5'-ACGTGAGAGCCCCGCTGAACGT-3' } \\
\hline Bax FI2 & G & 5'-GGCATTAGAGCTGCGATTGGACTGG-3' & $209 \mathrm{bp}$ & \\
\hline Bax RI2 & A & 5'-AGTGGCGCCGTCCAACAGCAGT-3' & $160 \mathrm{bp}$ & \\
\hline \multicolumn{5}{|c|}{ Fo-outer forward primer: $\mathrm{Fl}$ - Inner forward primer, Ro-outer reverse primer : } \\
\hline \multicolumn{5}{|c|}{ Rl-outer reverse primer } \\
\hline
\end{tabular}

\section{Preparation of PCR cocktail :}

The ARMS-PCR was performed in a reaction volume of $25 \mu \mathrm{L}$ containing template DNA (50ng), FO $-0.30 \mu \mathrm{L}, \mathrm{RO}-0.30 \mu \mathrm{L}, \mathrm{FI}-0.20 \mu \mathrm{L}, \mathrm{RI}-0.20 \mu \mathrm{L}$ of $25 \mathrm{pmol}$ of each primer and $10 \mu \mathrm{L}$ from GoTaq ${ }^{\circledR}$ Green Master Mix (cat no M7122) (Promega, USA). The final volume of $25 \mu \mathrm{L}$ was adjusted by adding nucleasefree ddH2O. Finally, $2 \mu \mathrm{L}$ of DNA was added from each patient.

\section{Thermocycling conditions:}

The amplification conditions used were at $95 \mathrm{oC}$ for 10 minutes followed by 45 cycles of $95 \mathrm{oC}$ for $35 \mathrm{sec}$, $58 \mathrm{oC}$ for $40 \mathrm{sec}, 72 \mathrm{oC}$ for $45 \mathrm{sec}$, followed by the final extension at $72 \mathrm{oC}$ for 10 minutes. The amplification products were separated by electrophoresis on $2 \%$ agarose gel, stained with $0.5 \mu \mathrm{g} / \mathrm{mL}$ ethidium bromide, and visualized on a UV Transilluminator.

\section{Optimization by a gradient PCR :}

The best temperature for $\mathrm{Bcl}-2-938 \mathrm{C}>\mathrm{A}$ rs2279115 SNP was determined to be $58^{\circ} \mathrm{C}$ in the temperature range of $55^{\circ} \mathrm{C}$ to $62^{\circ} \mathrm{C}$ tested with a gradient PCR thermocycler. In addition, the number of cycles was increased from 30 to 40 cycles, significantly enhancing the yields of all three PCR products. Similarly, the best temperature for Bax G $(-248)$ A SNP was achieved to be $68^{\circ} \mathrm{C}$ in the temperature range of $55^{\circ} \mathrm{C}$ to $65^{\circ} \mathrm{C}$ tested with a gradient PCR thermocycler. Robust amplification of the mutant allele was achieved by 
the above changes and a less competing reaction from the control, as shown by the relative intensities of the corresponding bands on agarose gel electrophoresis.

\section{Gel electrophoresis :}

For Bcl-2 -938 C > A SNP: Primers Fo and Ro of Bcl-2 gene resulting in a band of 300 bp to control DNA quality and quantity. Primers Fwt and Ro amplify a wild-type allele ( $C$ allele), generating a band of $121 \mathrm{bp}$, and primers Fo and Rmt generate a band of 220 bp from the mutant allele (A allele) as depicted in Fig. 1.

\section{For Bax G (- 248) A SNP:}

Primers Fo and Ro of Bax2 gene resulting in a band of 323 bp to act as a control for DNA quality and quantity. In addition, primers Fwt and Ro amplify a wild-type allele ( $G$ allele), generating a band of 209 bp, and primers Fo and Rmt generate a band of 160 bp from the mutant allele (A allele) as depicted in Fig. 2.

\section{Statistical analysis:}

Group differences were compared using the Student's two-sample t-test or one-way analysis of variance (ANOVA) for continuous variables and Chi-squared for categorical variables. Deviations from HardyWeinberg disequilibrium (HWD) were calculated by Chi-square $(X 2)$ goodness-of-fit test. The differences in the $\mathrm{Bcl}-2$ and $\mathrm{Bax}$ gene allele and genotype frequencies between groups were evaluated using the Chisquare test. The associations between Bcl-2 -938 C > A rs2279115 SNP and Bax G (-248)A SNP genotypes and leukemia cases were estimated by computing the odds ratios (ORs), risk ratios (RRs), and risk differences (RDs) with 95\% confidence intervals (Cls). Allele frequencies among cases and controls were evaluated using the Chi-square Hardy-Weinberg equilibrium test. A p-value $<0.05$ was considered significant. All statistical analyses were performed using Graph Pad Prism 8.4 and SPSS.

\section{Results}

\section{Demographic Characteristics of study population:}

Demographic data of Cases and Controls is demonstrated in Table 2. Among the study population, 78 (78\%) were males patients, and 22 (22\%) were female patients, whereas in the case of controls, 65 (65\%) and $35(35 \%)$ were males and female pateints, respectively. In the patient group, $60(60 \%)$ were having age $>40$ years, and $40(40 \%)$ were in $<40$ years age group. Whereas in the case of the control group, 60 $(60 \%)$ were having age $>40$ years and $40(40 \%)$ were in $<40$ years age group. Of $100 \mathrm{CML}$ cases, 40 (40\%) were below 40 years of age, and 60 (60\%) were above 40 . Of $100 \mathrm{CML}$ cases, 25(43.10\%) were in early-stage (chronic phases), 20 (34.48\%) were in accelerated phase, and 13(22.41\%) were in Blast crisis. 
Table 2

Demographic Characteristics of the study population

\begin{tabular}{|c|c|c|c|c|}
\hline & \multicolumn{2}{|l|}{ PATIENTS } & \multicolumn{2}{|c|}{ CONTROLS } \\
\hline & & $N=100(\%)$ & & $N=100(\%)$ \\
\hline \multirow[t]{3}{*}{ Age } & Years & & Years & \\
\hline & $>40$ & 60 (60\%) & $>40$ & 65 (65\%) \\
\hline & $<40$ & $40(40 \%)$ & $<40$ & 35 (35\%) \\
\hline \multirow[t]{2}{*}{ Gender } & Males & 78(78\%) & Males & $60(60 \%)$ \\
\hline & Females & $22(22 \%)$ & Females & $40(40 \%)$ \\
\hline \multirow[t]{4}{*}{ Stage } & TYPE & & $N=58$ & \\
\hline & CP-CML & & $25(43.10 \%$ & \\
\hline & AP-CML & & $20(34.48 \%$ & \\
\hline & BC-CML & & $13(22.41 \%$ & \\
\hline \multirow[t]{4}{*}{ MPD } & TYPE & & $N=33$ & \\
\hline & MPD (ET) & & $15(45.45 \%$ & \\
\hline & MPD PV & & $12(36.36 \%$ & \\
\hline & MPD MF & & $06(18.18 \%$ & \\
\hline \multirow[t]{2}{*}{ CLL } & TYPE & & $N=09$ & \\
\hline & CLL & & $09(6 \%)$ & \\
\hline
\end{tabular}

We observed a statistically significant difference in the frequencies of Bcl-2 -938 C > A rs2279115 CC, CA, and AA genotypes between leukemia patients and healthy controls $(p=0.025)$ as depicted in Table 3 . The AA homozygote is significantly overrepresented among patients compared to controls ( $22 \%$ vs. $10 \%)$. At the same time, $\mathrm{CC}$ homozygotes being significantly overrepresented among controls compared to patients ( $34 \%$ vs. $49 \%$ ). The frequency of the A allele ( $\mathrm{fA}$ ) was found to be higher among patients ( $44 \%)$ than the healthy controls (31\%), whereas a higher frequency of $\mathrm{C}$ allele (fC) was observed in healthy controls $(67 \%)$ than the patients $(56 \%)$ as depicted in Table 3 . The A allele appears to act as a risk allele, whereas the $\mathrm{C}$ allele appears to be protective. 
Table 3

Association of Bcl-2 -938 C > A rs2279115 gene polymorphism between case and controls

\begin{tabular}{|lcllllllll|}
\hline Subjects & $\mathbf{N}=$ & $\begin{array}{l}\text { CC } \\
\text { genotype } \\
\%\end{array}$ & $\begin{array}{l}\text { CA } \\
\text { genotype } \\
\%\end{array}$ & $\begin{array}{l}\text { AA } \\
\text { genotype\% }\end{array}$ & $\begin{array}{l}\text { C } \\
\text { allele }\end{array}$ & $\begin{array}{l}\text { A } \\
\text { allele }\end{array}$ & DF & X2 & $\begin{array}{l}\text { P } \\
\text { value }\end{array}$ \\
\hline $\begin{array}{l}\text { Leukemia } \\
\text { cases }\end{array}$ & 100 & $34(34 \%)$ & $44(44 \%)$ & $22(22 \%)$ & $\begin{array}{l}0.56 \\
(56 \%)\end{array}$ & $\begin{array}{l}0.44 \\
(44 \%)\end{array}$ & 2 & 7.32 & 0.025 \\
$\begin{array}{l}\text { Healthy } \\
\text { controls }\end{array}$ & 100 & $49(49 \%)$ & $41(41 \%)$ & $10(10 \%)$ & $\begin{array}{l}0.67 \\
(67 \%)\end{array}$ & $\begin{array}{l}0.31 \\
(31 \%)\end{array}$ & & & \\
\hline
\end{tabular}

Bcl-2 -938 C > A genotypes association with clinicalpathological features of the Leukemia patients:

We observed a significant difference of Bcl-2 -938 C > A genotypes for CML stages $(P=0.04)$, especially between chronic and accelerated phases. We do not observe any significant difference in the frequencies of Bcl-2 -938 genotypes CC, CA \& AA to the age and gender (Table 4). A non-significant correlation was reported between Bcl-2 -938 C > A genotypes and different types of MPDs. In CML, patients in chronicphase (CP) had a higher frequency of heterozygosity of CA genotype $(60 \%)$ than acute-phase (AP) $(25 \%)$ as well as blast-crises (BC) phase (46\%)(Table 4). Higher frequency AA genotype was reported in the AP phase than $\mathrm{CP}(25 \%)$ and $\mathrm{BC}$ phase (15\%).In the case of the BC-phase, the highest frequency of CC genotype (50\%) compared to CP-phase (20\%)and AP-Phase (20\%) (Table 4). We observed a statistically significant difference in the frequencies of $\mathrm{Bcl}-2-938 \mathrm{C}>\mathrm{A}$ genotypes between CP-Phase and AP-Phase $(p<0.04)$. 
Table 4

Clinical correlation of Bcl-2 -938 genotypes with clinical-pathological features of the Leukemia patients
Gender
$N=$
100
CC \%
$\mathrm{CA} \%$
(AA) \%
Df $\quad \mathrm{X} 2$
value

Correlation of Bcl-2 -938 C > A with the age of leukemia cases

$\begin{array}{lllllllll}\text { Age } & >40 & 60 & \begin{array}{l}20 \\ (33.33 \%)\end{array} & 30(50 \%) & 10(16.66 \%) & 2 & 3.19 & 0.20 \\ & <40 & 40 & 14(35 \%) & 14(35 \%) & 12(30 \%) & \end{array}$

Correlation of Bcl-2 -938 C > A with the gender of leukemia cases

\begin{tabular}{|c|c|c|c|c|}
\hline Males & 78 & $\begin{array}{l}28 \\
(35.89 \%)\end{array}$ & $\begin{array}{l}36 \\
(46.15 \%)\end{array}$ & $\begin{array}{l}14 \\
(17.95 \%)\end{array}$ \\
\hline
\end{tabular}

\begin{tabular}{|c|c|c|}
\hline Eemales & 22 & $\begin{array}{l}06 \\
(27.27 \%)\end{array}$ \\
\hline
\end{tabular}

Correlation of Bcl-2 -938 C > A with CP-CML vs. AP-CML

$\begin{array}{lllllllll} & & \mathrm{N}=70 & 20 & 35 & 15 & & & \\ \text { Stage } & \text { CP-CML } & 25 & 5(20 \%) & 15(60 \%) & 5(20 \%) & 2 & 5.43 & 0.04 \\ & \text { AP-CML } & 20 & 10(50 \%) & 5(25 \%) & 5(25 \%) & & & \end{array}$

Correlation of Bcl-2 -938 C > A with CP-CML vs. BC-CML

$\begin{array}{llllllll}\text { CP-CML } & 25 & 5(20 \%) & 15(60 \%) & 5(20 \%) & 2 & 1.5 & 0.47 \\ \text { BC-CML } & 13 & 5(38.46 \%) & 6(46.15 \%) & 2(15.38 \%) & & & \end{array}$

Correlation of Bcl-2 -938 C > A with MPD cases

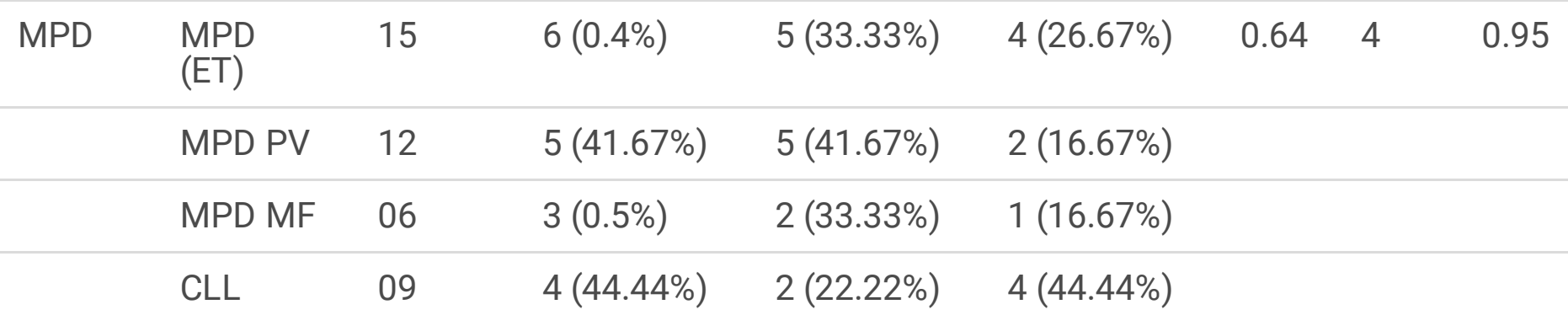

Multivariate analysis of Bcl-2 -938 C > A in leukemia patients :

An unconditional logistic regression was used to estimate associations between the genotypes and the risk of leukemia (Table 5). It was found that an increased risk of leukemia was associated with the Bcl-2AA genotype in an allele dosage-dependent manner. In the codominant model, the AA genotype of the Bcl2 was associated with susceptibility to leukemia with $O R=3.17(1.33-7.53), R R=1.88(1.09-3.25), P<$ 0.009 . The dominant model $(C A+A A)$ is associated with increased susceptibility to leukemia with $O R=$ 
1.86(1.05-3.29), $R R=1.35(1.030-1.77), P<0.03$. The recessive model, $(C C+C A) V S(A A)$ is associated with increased susceptibility to leukemia with $O R=2.53(1.13-5.68), R R=1.71(1.006-2.92), P<0.02$. The $\mathrm{Bcl}-2$-938 C > A rs2279115 A allele is associated with increased susceptibility to leukemia (OR = 1.79(1.18-2.69), $R R=135(1.08-1.68), P<0.007)$ (Table 5).

Table 5

Multivariate analysis of the association of Bcl-2 -938 C > A genotypes with Leukemia susceptibility

\begin{tabular}{|c|c|c|c|c|c|}
\hline & $\begin{array}{l}\text { Healthy } \\
\text { controls }\end{array}$ & $\begin{array}{l}\text { Leukemia } \\
\text { patients }\end{array}$ & & & \\
\hline Genotypes & $(N=100)$ & $(N=100)$ & OR (95\% Cl) & Risk Ratio(RR) & P-Val \\
\hline \multicolumn{6}{|l|}{ Codominant } \\
\hline Bcl-2-CC & $49(49 \%)$ & $34(34 \%)$ & 1 (ref.) & 1 (ref.) & \\
\hline $\mathrm{Bcl}-2-\mathrm{CA}$ & $41(41 \%)$ & $44(44 \%)$ & $\begin{array}{l}1.54(0.84- \\
2.84)\end{array}$ & $1.22(0.92-1.62)$ & 0.16 \\
\hline $\mathrm{Bcl}-2-\mathrm{AA}$ & $10(10 \%)$ & $22(49 \%)$ & $\begin{array}{l}3.17(1.33- \\
7.53)\end{array}$ & $1.88(1.09-3.25)$ & 0.009 \\
\hline \multicolumn{6}{|l|}{ Dominant } \\
\hline Bcl-2-CC & $49(49 \%)$ & $34(34 \%)$ & 1 (ref.) & 1 (ref.) & \\
\hline $\begin{array}{l}\mathrm{Bcl}-2-(\mathrm{CA}+ \\
\mathrm{AA})\end{array}$ & $51(51 \%)$ & $66(66 \%)$ & $\begin{array}{l}1.86(1.05- \\
3.29)\end{array}$ & $\begin{array}{l}1.35(1.030- \\
1.77)\end{array}$ & 0.03 \\
\hline \multicolumn{6}{|l|}{ Recessive } \\
\hline $\begin{array}{l}\mathrm{Bcl}-2(\mathrm{CC}+ \\
\mathrm{CA})\end{array}$ & $90(90 \%)$ & $78(78 \%)$ & 1 (ref.) & 1 (ref.) & \\
\hline $\mathrm{Bcl}-2$ (AA) & $10(10 \%)$ & $22(22 \%)$ & $\begin{array}{l}2.53(1.13- \\
5.68)\end{array}$ & $\begin{array}{l}1.71(1.006- \\
2.92)\end{array}$ & 0.02 \\
\hline \multicolumn{6}{|l|}{ Allele } \\
\hline $\mathrm{Bcl}-2-\mathrm{C}$ & $139(69.5 \%)$ & $112(56 \%)$ & 1 (ref.) & 1 (ref.) & \\
\hline Bcl-2-A & $61(30.5 \%)$ & $88(44 \%)$ & $\begin{array}{l}1.79(1.18- \\
2.69)\end{array}$ & $135(1.08-1.68)$ & 0.005 \\
\hline
\end{tabular}


Table 5

Multivariate analysis of the association of $\mathrm{Bcl}-2$-938 C > A genotypes with Leukemia susceptibility in Leukemia patients

\begin{tabular}{|c|c|c|c|c|c|}
\hline & $\begin{array}{l}\text { Healthy } \\
\text { controls }\end{array}$ & $\begin{array}{l}\text { Leukemia } \\
\text { patients }\end{array}$ & & & \\
\hline Genotypes & $(N=100)$ & $(N=100)$ & OR $(95 \% \mathrm{Cl})$ & Risk Ratio(RR) & P-Val \\
\hline \multicolumn{6}{|l|}{ Codominant } \\
\hline Bcl-2-CC & $49(49 \%)$ & $34(34 \%)$ & 1 (ref.) & 1 (ref.) & \\
\hline $\mathrm{Bcl}-2-\mathrm{CA}$ & $41(41 \%)$ & $44(44 \%)$ & $\begin{array}{l}1.54(0.84- \\
2.84)\end{array}$ & $1.22(0.92-1.62)$ & 0.16 \\
\hline $\mathrm{Bcl}-2-\mathrm{AA}$ & $10(10 \%)$ & $22(49 \%)$ & $\begin{array}{l}3.17(1.33- \\
7.53)\end{array}$ & $1.88(1.09-3.25)$ & 0.009 \\
\hline \multicolumn{6}{|l|}{ Dominant } \\
\hline $\mathrm{Bcl}-2-\mathrm{CC}$ & $49(49 \%)$ & $34(34 \%)$ & 1 (ref.) & 1 (ref.) & \\
\hline $\begin{array}{l}\mathrm{Bcl}-2-(\mathrm{CA}+ \\
\mathrm{AA})\end{array}$ & $51(51 \%)$ & $66(66 \%)$ & $\begin{array}{l}1.86(1.05- \\
3.29)\end{array}$ & $\begin{array}{l}1.35(1.030- \\
1.77)\end{array}$ & 0.03 \\
\hline \multicolumn{6}{|l|}{ Recessive } \\
\hline $\begin{array}{l}\mathrm{BCl}-2(\mathrm{CC}+ \\
\mathrm{CA})\end{array}$ & $90(90 \%)$ & 78(78\%) & 1 (ref.) & 1 (ref.) & \\
\hline $\mathrm{Bcl}-2$ (AA) & $10(10 \%)$ & $22(22 \%)$ & $\begin{array}{l}2.53(1.13- \\
5.68)\end{array}$ & $\begin{array}{l}1.71(1.006- \\
2.92)\end{array}$ & 0.02 \\
\hline \multicolumn{6}{|l|}{ Allele } \\
\hline $\mathrm{Bcl}-2-\mathrm{C}$ & $139(69.5 \%)$ & $112(56 \%)$ & 1 (ref.) & 1 (ref.) & \\
\hline Bcl-2-A & $61(30.5 \%)$ & $88(44 \%)$ & $\begin{array}{l}1.79(1.18- \\
2.69)\end{array}$ & $135(1.08-1.68)$ & 0.005 \\
\hline
\end{tabular}

\section{Genotype distribution of Bax-248G > A genotypes between cases and controls}

We observed a statistically significant difference in the frequencies of Bax-248 G > A GG, GA, and AA genotypes between leukemia patients and healthy controls $(P=0.048)$, as depicted in Table 6 . The AA genotype was significantly overrepresented among patients compared to controls (6.48\% vs. $4.58 \%)$, whereas GG homozygotes were significantly overrepresented among controls compared to patients $(41.66 \%$ vs. $27.275 \%)$. The frequency of the $A$ allele $(f A)$ was found to be higher among patients $(0.27)$ than the healthy controls ( 0.18$)$, whereas a higher frequency of $G$ allele ( $f G$ ) was observed in healthy controls (0.82) than the patients (0.73) as depicted in Table 4. The A allele appears to act as a risk allele, whereas the $\mathrm{G}$ allele appears to be protective. 
Table 6

Association of Bax-248G > A gene polymorphism between case and controls

\begin{tabular}{|lcllllllll|}
\hline & N= & GG & GA & AA & $\begin{array}{l}\text { G } \\
\text { allele }\end{array}$ & $\begin{array}{l}\text { A } \\
\text { allele }\end{array}$ & DF & X2 & $\begin{array}{l}\text { P } \\
\text { value }\end{array}$ \\
\hline $\begin{array}{l}\text { Leukemia } \\
\text { cases }\end{array}$ & 108 & $56(51.85 \%)$ & genotype \% & $\begin{array}{l}\text { genotype } \\
\%\end{array}$ & & & & & \\
\hline $\begin{array}{l}\text { Healthy } \\
\text { controls }\end{array}$ & 110 & $75(68.5 \%)$ & $30(27.27 \%)$ & $5(4.54 \%)$ & 0.82 & 0.18 & & & \\
\hline
\end{tabular}

\section{Clinical correlation of Bax-248G > A genotypes with clinicopathological features of leukemia patients}

We observed a significant difference in the frequencies of Bax-248 G > A genotypes GG, GA \& AA for the age of the leukemia patients. A higher frequency of AA genotype was reported in older age leukemia patients than the younger ones $(p=0.001)$ (Table 7). A non-significant correlation was noted between Bax-248G > A genotypes and gender. There is a non-significant difference in Bax-248 G > A genotypes for $C M L$ stages $(P=0.98)$. A non-significant correlation was also reported between Bax-248G $>A$ genotypes and different types of MPDs. In CML patients, a higher frequency of AA genotype was reported in the blastic phase (10\%) than in $\mathrm{CP}$ and $\mathrm{BC}$ phase. 
Table 7

Association of Bax-248G > A gene polymorphism with clinicopathological features Leukemia patients

$\begin{array}{lllllll}\mathrm{N}= & \mathrm{GG}(56) & \mathrm{GA}(45) & \mathrm{AA}(07) & \mathrm{Df} & \mathrm{X} 2 & \begin{array}{l}\mathrm{P} \\ \text { value }\end{array}\end{array}$

Correlation of Bax-248G > A genotypes with the age of leukemia cases

$\begin{array}{lllllllll}\text { Age } & >40 & 63 & 26(41.26 \%) & 35(55.55 \%) & 02(3.17 \%) & 2 & 12.82 & 0.001 \\ & <40 & 45 & 30(66.66 \%) & 10(22.22 \%) & 05(11.11 \%) & & & \end{array}$

Correlation of Bax-248G > A genotypes with the gender of leukemia cases

\begin{tabular}{lllllllll} 
Gender & Males & 73 & 36 & 33 & $03(4.11 \%)$ & 2 & 2.83 & 0.24 \\
& & & $(49.32 \%)$ & $(45.21 \%)$ & & & & \\
\cline { 2 - 8 } & Females & 35 & 20 & 12 & 04 & & & \\
& & & $(57.14 \%)$ & $(34.29 \%)$ & $(11.43 \%)$ & & &
\end{tabular}

Correlation of Bax-248G > A genotypes with the stage of leukemia cases

\begin{tabular}{lllllllll} 
Stage & CP-CML & 30 & $\begin{array}{l}14 \\
(46.67 \%)\end{array}$ & $\begin{array}{l}13 \\
(43.33 \%)\end{array}$ & $03(1 \%)$ & 2 & 0.31 & 0.98 \\
\cline { 2 - 8 } & AP-CML & 14 & $\begin{array}{l}06 \\
(42.86 \%)\end{array}$ & $07(0.5 \%)$ & $01(7.14 \%)$ & & \\
& & & & & & \\
& BC-CML & 10 & $04(40 \%)$ & $05(50 \%)$ & $01(10 \%)$ & &
\end{tabular}

Correlation of Bax-248G > A genotypes with the stage of leukemia cases

\begin{tabular}{|c|c|c|c|c|c|c|c|c|}
\hline \multirow[t]{3}{*}{$\begin{array}{l}\text { MPD } \\
\text { types }\end{array}$} & $\begin{array}{l}\text { MPD } \\
(\mathrm{ET})\end{array}$ & 30 & $18(6 \%)$ & $\begin{array}{l}11 \\
(36.67 \%)\end{array}$ & 1 (3.33\%) & 4 & 0.80 & 0.93 \\
\hline & MPD PV & 16 & $10(62.5 \%)$ & $\begin{array}{l}05 \\
(31.25 \%)\end{array}$ & $1(6.25 \%)$ & & & \\
\hline & MPD MF & 04 & $02(0.5 \%)$ & $2(0.5 \%)$ & $0(0 \%)$ & & & \\
\hline ALL & ALL & 4 & $2(0.5 \%)$ & $2(0.5 \%)$ & $0(0 \%)$ & & & \\
\hline
\end{tabular}

\section{Multivariate analysis of Bax-248G > A in leukemia patients}

An unconditional logistic regression was used to estimate associations between the genotypes and risk of leukemia (Table 8). It was found that an increased risk of leukemia was associated with the Bax-248 GG genotype. In the codominant model, the GG genotype of the Bax-248 G > A SNP was associated with increased susceptibility to leukemia with $O R=2.0(1.12-3.57), R R=1.43(1.045-1.95) P<0.017$. In the case of the dominant model, $(G A+A A)$ vs. $G G$ is associated with increased susceptibility to leukemia with $O R=1.98(1.14-3.45), R R=1.43(1.05-1.91), P<0.014$. In the case of the recessive model $(G G+G A) V S$ (AA), no significant association to leukemia susceptibility was reported. Our results indicated that $A$ allele of Bax-248 G > A SNP is associated with increased susceptibility to leukemia $(\mathrm{OR}=1.63(1.03-2.58), \mathrm{RR}=$ 1.29(1.00-1.67), $\mathrm{P}<0.035)$ (Table 8). 
Table 8

Association of Bax-248G > A gene polymorphism with Leukemia Patients

\begin{tabular}{|c|c|c|c|c|c|c|c|}
\hline \multirow[t]{2}{*}{ Genotypes } & \multicolumn{2}{|c|}{$\begin{array}{l}\text { Healthy } \\
\text { controls }\end{array}$} & \multicolumn{2}{|c|}{$\begin{array}{l}\text { Leukemia } \\
\text { patients }\end{array}$} & OR $(95 \% \mathrm{Cl})$ & Risk Ratio(RR) & P-Val \\
\hline & \multicolumn{2}{|c|}{$(N=110) \%$} & \multicolumn{3}{|c|}{$(N=108) \%$} & & \\
\hline \multicolumn{8}{|l|}{ Codominant } \\
\hline Bax-GG & 75 & $68.18 \%$ & 56 & $51.85 \%$ & 1 (ref.) & 1 (ref.) & \\
\hline $\mathrm{Bax}-\mathrm{GA}$ & 30 & $27.27 \%$ & 45 & $41.66 \%$ & $2.0(1.12-3.57)$ & $\begin{array}{l}1.43(1.045- \\
1.95)\end{array}$ & 0.017 \\
\hline $\mathrm{Bax}-\mathrm{AA}$ & 05 & $4.54 \%$ & 07 & $4.68 \%$ & $\begin{array}{l}1.87(0.56- \\
6.21)\end{array}$ & $1.37(0.69-2.72)$ & 0.30 \\
\hline \multicolumn{8}{|l|}{ Dominant } \\
\hline Bax-GG & 75 & 68.18 & 56 & $51.85 \%$ & 1 (ref.) & 1 (ref.) & \\
\hline $\operatorname{Bax}(\mathrm{GA}+\mathrm{AA})$ & 35 & 31.82 & 52 & $48.15 \%$ & $\begin{array}{l}1.98(1.14- \\
3.45)\end{array}$ & $1.43(1.05-1.91)$ & $\begin{array}{l}0 . \\
014\end{array}$ \\
\hline \multicolumn{8}{|l|}{ Recessive } \\
\hline $\begin{array}{l}\mathrm{Bax}(\mathrm{GG}+ \\
\mathrm{G} A)\end{array}$ & 105 & 95.45 & 101 & $93.52 \%$ & 1 (ref.) & 1 (ref.) & \\
\hline $\operatorname{Bax}(\mathrm{AA})$ & 05 & 4.55 & 07 & $6.48 \%$ & $\begin{array}{l}1.45(0.44- \\
4.73)\end{array}$ & $1.23(0.61-2.42)$ & 0.53 \\
\hline \multicolumn{8}{|l|}{ Allele } \\
\hline Bax-G & 180 & 81.82 & 157 & $73.36 \%$ & 1 (ref.) & 1 (ref.) & \\
\hline Bax-A & 40 & 18.18 & 57 & $26.63 \%$ & $\begin{array}{l}1.63(1.03- \\
2.58)\end{array}$ & $1.29(1.00-1.67)$ & 0.035 \\
\hline
\end{tabular}

\section{Discussion}

Myeloproliferative Neoplasms (MPNs) are disorders of blood stem cells characterized by uncontrolled development of mature blood cells [18]. Although there are no clear distinctions between these disorders, they can present in various disease categories and transform into one another [19].

Allelic polymorphisms in the promoter region of specific genes may cause qualitative or quantitative changes by affecting the transcription factor binding site or other gene regulatory sites. Many singlenucleotide polymorphisms (SNPs) are accumulated to aid in developing cancers or in mechanisms such as apoptosis, which play a crucial role in chemotherapeutic resistance $[20,21]$. Thus, in this study, the role of SNPs involved in the apoptotic pathway; Bax - $248 \mathrm{G}>\mathrm{A}$ (rs4645878), and Bcl-2 -938 C > A 
(rs2279115), were investigated in terms of their molecular effects on different MPNs; Chronic myeloid leukemia (CML), Polycythemia vera (PV), and Essential thrombocythemia (ET)

BCL-2 protein has multiple effects in tumorigenesis, which may explain why Bcl-2 over-expression is important in diagnosing various tumors depending on the type of tumor. Polymorphisms in the Bcl-2 gene may alter its anti-apoptotic role and serve as an important marker to guide targeted treatments [22, 23]. The P2 promoter polymorphisms of the Bcl-2 gene were investigated in our study. Control subjects did not differ significantly from those with PV or ET in terms of genotype ratios and allele frequencies of the Bcl2 -938 C > A (rs2279115) polymorphism ( $p>0.05)$. However, in CML, Bcl-2 gene expression differs in compared to normal control. In support, Moon et al. proposed that a BCL- 2 gene expression could be used as a post-chemotherapy diagnostic marker for Myeloid leukemia. In patients with AML, Bcl-2 expression is known to be increased following Bcl-2 induction [24]. Furthermore, AML patients with higher BCL-2 protein or gene expression have a shorter survival time and a poor response to chemotherapy. Moon et al. concluded that the Bcl-2 $938 \mathrm{C}>\mathrm{A}$ polymorphism was associated with overall survival and remission rates following chemotherapy in leukemia patients [24]. In a study involving patients with CLL, Nückel et al. discovered that the AA genotype in the Bcl-2 $938 \mathrm{C}>\mathrm{A}$ polymorphism was associated with increased transcription of $\mathrm{Bcl}-2$ and that it might be possible to use this as a predictive genetic biomarker in patients with CLL [11]. In addition, Hwan et al. found a link between the Bcl-2938 polymorphism and the risk of developing $\mathrm{CML}$, a clonal myeloproliferative disease [25].

The genotype ratios of Bax-248 G > A (rs4645878) polymorphisms were not significantly different between control subjects and patients with PV or ET. This results supported by Skogsberg et al. that the Bax-248 polymorphism played no part in luekemia survival or prognosis [26]. However, Saxena et al. reported that the Bax - 248 polymorphism, which occurs in the Bax promoter, is linked to reduced Bax expression in luekemia and the inability to produce a complete response to conventional therapy. Similar results are also seen in solid cancers $[27,28]$. Another study by Feng et al. found that despite no role of Bax rs4645878 in cancerogenesis, it may correlate to adverse prognosis in some cancers [29].

\section{Conclusion}

The presence of this single nucleotide polymorphism in BCL2 -938 C >A and BAX-248G > A in leukemia patients critically increases the susceptibility to leukemia influences the response to treatment and overall survival. Our data indicated that A allele of BCL2-938 C > A and BAX-248G > A gene significantly increased the risk of developing the leukemia compared to $G$ allele. The data from the current study provide evidence that BCL2-938C > A and BAX-248G > A polymorphisms may be useful in predicting clinical outcomes of patients with leukemia.

\section{Declarations}

\section{Competing interests:-}


The authors declare that they have no competing interests.

\section{Authors' contributions:-}

All authors read and approved the final manuscript. Thanks to all authors for their support and help in this study.

\section{Acknowledgments:-}

We would like to acknowledge the technical support from the Prince Fahd Bin Sultan Research chair, University of Tabuk.

\section{* Funding Info :}

This work was supported by grants from the Deanship of Scientific Research (1441-0121), University of Tabuk. Saudi Arabia.

* Conflicts of interest/Competing interests:The authors declare that they have no competing interests.

* Ethics statement :This research study was ethically approved by institution etthics committee universiyy of Tabuk -Approval No-UT-88-19-2019

* Consent to participate and for publication:The samples were collected after the approval letter was obtained from the concerned Institutional Ethics Committee. All patients obtained Patient consent forms before sampling.

Authors' contributions - mandatory

Dr Rashid -contributed methodlogy ,write

* Availability of data and material

Dr Mamdouh Shafig Moawad- Original concept, Project administration, Reviewing manuscripts

Dr Faris J Tayeb-Writing manuscript, reviewing and methodology

Dr Rashid Mir- Design experiments, methodology and writing manuscript

\section{References}

1. NCI. SEER Cancer Statistics Review 1975-2018 (2021); Available from: https://seer.cancer.gov/csr/1975_2018/browse_csr.php?sectionSEL=2\&pageSEL=sect_02_table.01

2. IARC. Global Cancer Observatory: Cancer Today (2020) 21 November 2021]; Available from: http://gco.iarc.fr/today/home 
3. Bray F et al (2018) Global cancer statistics 2018: GLOBOCAN estimates of incidence and mortality worldwide for 36 cancers in 185 countries. Ca-a Cancer Journal for Clinicians 68(6):394-424

4. Cory S, Adams JM (2002) The BCL2 family: Regulators of the cellular life-or-death switch. Nat Rev Cancer 2(9):647-656

5. Kaur D, Deshmukh R (2021) Chap. 2 - Physiology of cellular demise: Apoptosis, necrosis, and autophagy, in Clinical Perspectives and Targeted Therapies in Apoptosis, R.K. Sodhi and J. Madan, Editors. Academic Press. p. 23-78

6. Llambi F et al (2011) A Unified Model of Mammalian BCL-2 Protein Family Interactions at the Mitochondria. Mol Cell 44(4):517-531

7. Strasser A, Cory S, Adams JM (2011) Deciphering the rules of programmed cell death to improve therapy of cancer and other diseases. EMBO J 30(18):3667-3683

8. Guo MJ et al (2021) Apoptosis detection: a purpose-dependent approach selection. Cell Cycle 20(11):1033-1040

9. Oltvai ZN, Milliman CL, Korsmeyer SJ (1993) BCL-2 Heterodimerizes In-Vivo With A Conserved Homolog, Bax, That Accelerates Programmed Cell-Death. Cell 74(4):609-619

10. Diepstraten ST et al (2021) The manipulation of apoptosis for cancer therapy using BH3-mimetic drugs.Nature Reviews Cancer,

11. Nuckel $\mathrm{H}$ et al (2007) Association of a novel regulatory polymorphism (-938C > A) in the BCL2 gene promoter with disease progression and survival in chronic lymphocytic leukemia. Blood 109(1):290297

12. Stolz C et al (2008) Targeting Bcl-2 family proteins modulates the sensitivity of B-cell lymphoma to rituximab-induced apoptosis. Blood 112(8):3312-3321

13. Chou $D$ et al (1996) The BAX gene maps to the glioma candidate region at $19 q 13.3$, but is not altered in human gliomas. Cancer Genet Cytogenet 88(2):136-140

14. Sahu SK, Choudhuri T (2013) Lack of Association between Bax Promoter (-248G > A) Single Nucleotide Polymorphism and Susceptibility towards Cancer: Evidence from a Meta-Analysis.Plos One, 8(10)

15. Linjawi A et al (2004) Prognostic significance of p53, bcl-2, and Bax expression in early breast cancer. J Am Coll Surg 198(1):83-90

16. Bukholm IK, Nesland JM (2000) Protein expression of p53, p21 (WAF1/CIP1), bcl-2, Bax, cyclin D1 and $p R b$ in human colon carcinomas. Virchows Archiv-an International Journal of Pathology, 436(3): p. 224-228

17. Starczynski $J$ et al (2005) Common polymorphism G(-248)A in the promoter region of the bax gene results in significantly shorter survival in patients with chronic lymphocytic leukemia once treatment is initiated. J Clin Oncol 23(7):1514-1521

18. Ma W et al (2010) JAK2 exon 14 deletion in patients with chronic myeloproliferative neoplasms. PLoS ONE 5(8):e12165-e12165 
19. Provan D, Gribben J (2010) Molecular hematology. John Wiley \& Sons

20. Knoefel LF et al (2011) Polymorphisms in the Apoptotic Pathway Gene BCL-2 and Survival in Small Cell Lung Cancer. J Thorac Oncol 6(1):183-189

21. Bonzheim I et al (2008) Analysis of single nucleotide polymorphisms in the FAS and CTLA-4 genes of peripheral T-cell lymphomas. J Hematop 1(1):11-21

22. Bachmann HS et al (2011) Regulatory BCL2 promoter polymorphism $(-938 \mathrm{C}>\mathrm{A})$ is associated with adverse outcome in patients with prostate carcinoma. Int J Cancer 129(10):2390-2399

23. Zhang $\mathrm{N}$ et al (2011) BCL-2 (-938C > A) polymorphism is associated with breast cancer susceptibility.Bmc Medical Genetics, 12

24. Moon JH et al (2010) BCL2 gene polymorphism could predict the treatment outcomes in acute myeloid leukemia patients. Leuk Res 34(2):166-172

25. Kim DH et al (2009) Genetic variants in the candidate genes of the apoptosis pathway and susceptibility to chronic myeloid leukemia. Blood 113(11):2517-2525

26. Skogsberg A et al (2006) The G(-248)A polymorphism in the promoter region of the Bax gene does not correlate with prognostic markers or overall survival in chronic lymphocytic leukemia. Leukemia 20(1):77-81

27. Alam M et al (2019) Role and regulation of proapoptotic Bax in oral squamous cell carcinoma and drug resistance. Head and Neck-Journal for the Sciences and Specialties of the Head and Neck. 41:185-1971

28. Saxena A et al (2002) Association of a novel single nucleotide polymorphism, G(-248)A, in the 5 'UTR of BAX gene in chronic lymphocytic leukemia with disease progression and treatment resistance. Cancer Lett 187(1-2):199-205

29. Feng $Y$ et al (2018) Prognostic value and susceptibility of BAX rs4645878 polymorphism in cancer $A$ systematic review and meta-analysis. Medicine 97(29):8

\section{Figures}


Figure 1: Gel electrophoresis (2\%) of BCL2 (Ala43Thr) C/T SNP in leukemia patients

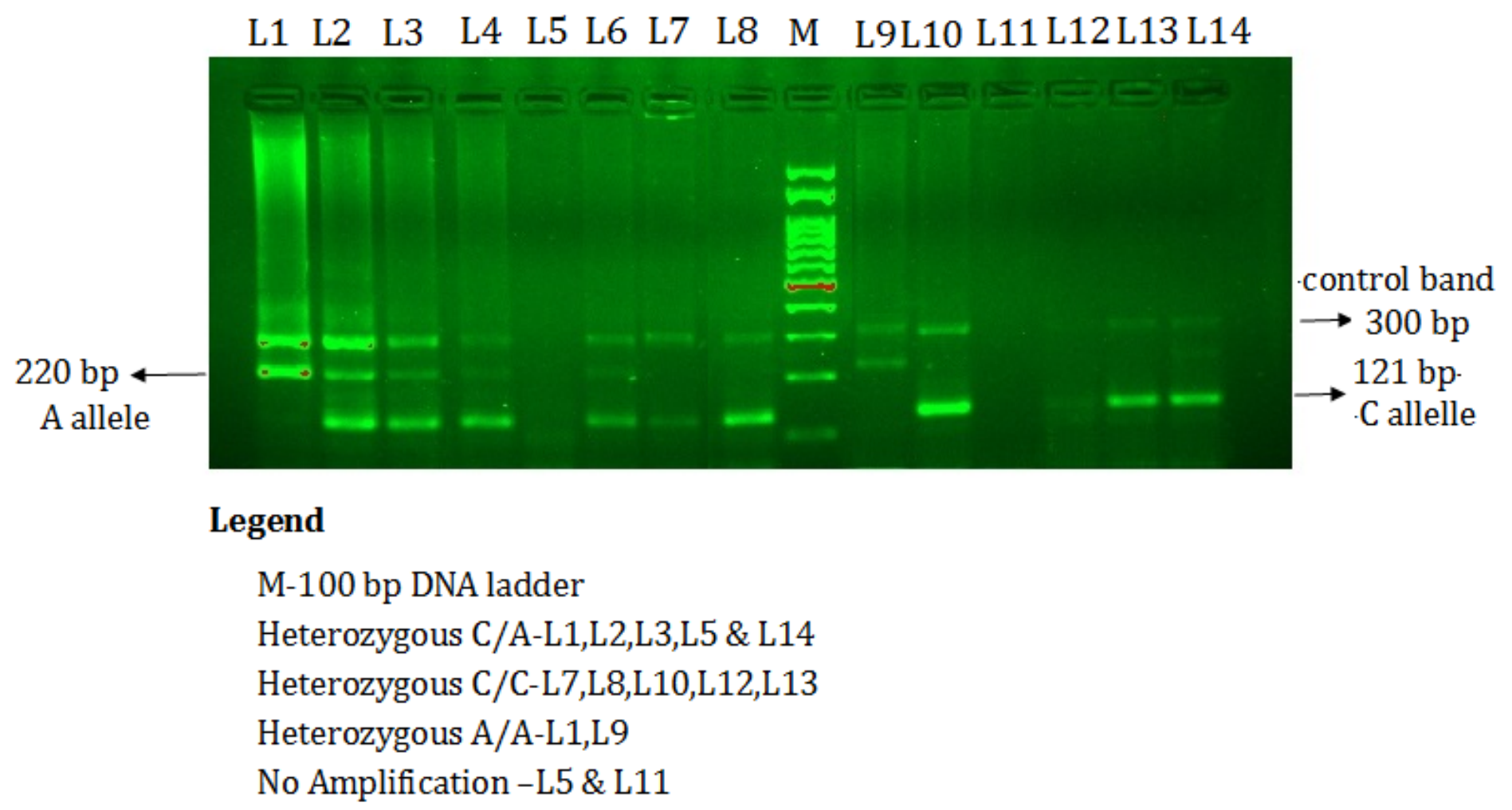

Figure 1

See image above for figure legend 
Figure 2: Gel electrophoresis (2\%) of Bax G(- 248)A SNP in leukemia patients by amplificationrefractory mutation system PCR.

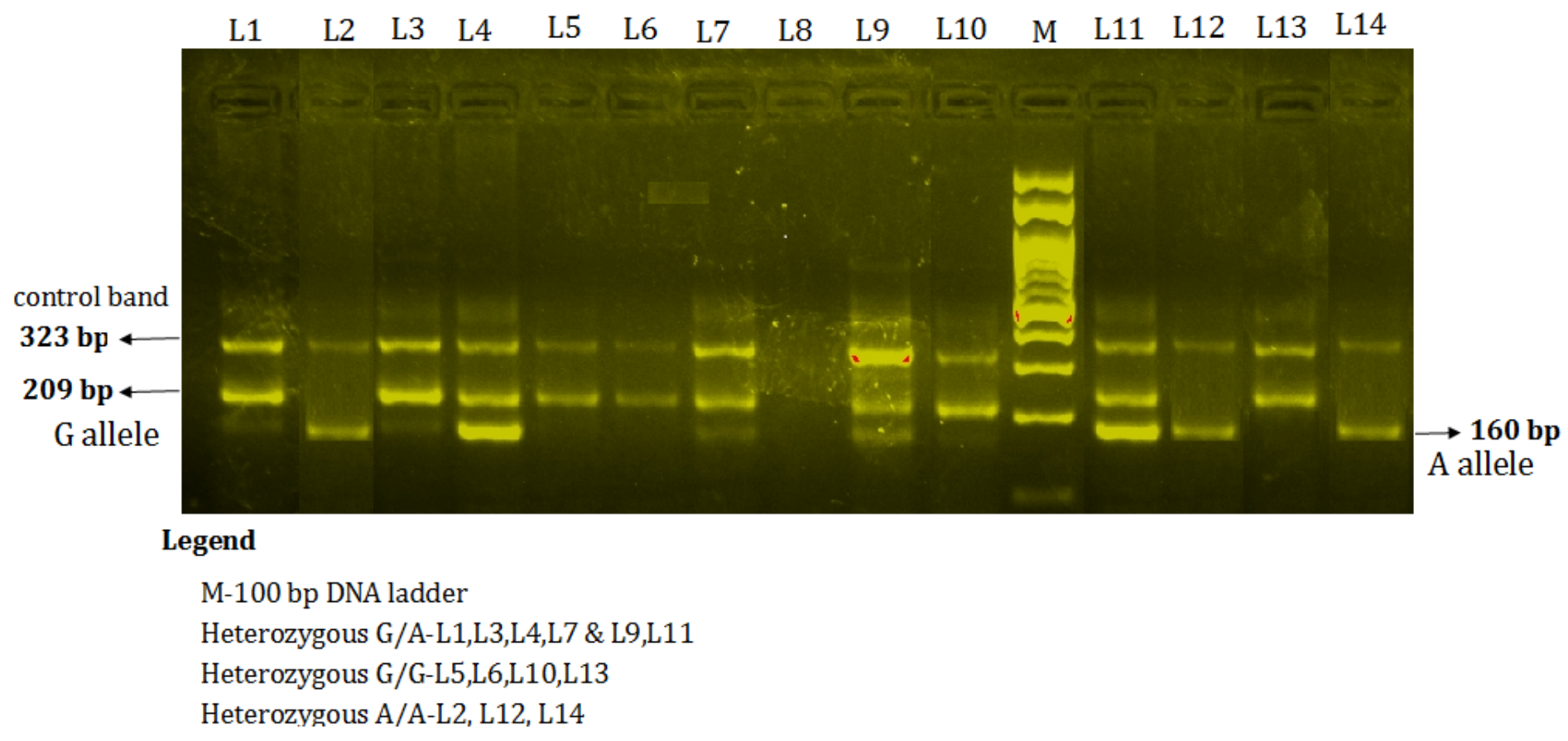

\section{Figure 2}

See image above for figure legend 